\title{
SOLDIER HEAD MORPHOLOGY OF THE NEOTROPICAL TERMITES: EMBIRATERMES FESTIVELLUS SILVESTRI AND SPINITERMES BREVICORNUTUS (DESNEUX) (ISOPTERA, TERMITIDAE)
}

\author{
Ana Maria Costa-Leonardo ${ }^{1}$ \\ Raquel Cristina Barsotti ${ }^{1}$
}

\begin{abstract}
Heads of soldier termites belonging to the species Embiratermes festivellus (Silvestri, 1901) (Termitidae, Nasutitermitinae) and Spinitermes brevicornutus (Desneux, 1904) (Termitidae, Termitinae) were examined using scanning electron microscopy. Individual glandular openings are present in the upper part of $E$. festivellus head and correspond to class 3 glandular cells. Campaniform sensillae occur in both termite heads, but this sensorial structure was not observed in the nasus extremity of E. festivellus soldier.

KEY WORDS. Isoptera, Embiratermes, Spinitermes, termite, campaniform sensillum
\end{abstract}

In Isoptera, the soldier caste has a role in defense, and a variety of specialized morphological structures have evolved in this caste. For example, termite soldiers may have powerful mandibles, and/or they may have a frontal gland that produces chemical substances used in defense.

Embiratermes festivellus (Silvestri, 1901) and Spinitermes brevicornutus (Desneux, 1904) are termite species found in areas of the Brazilian cerrado. In addition to distinctive mandibles, the soldiers of E. festivellus have a rostral tube which is used to eliminate the frontal secretion. The soldier of S. brevicornutus has slashing mandibles, with an angular motion that enables it cross over each other in the fight. Soldiers of $E$. festivellus have piercing mandibles that are common in mandibulate nasutes. In some of these mandibulate nasutes, the piercing may be accompanied by chemicals entering the wound from the frontal gland (PRESTWICH 1984).

In this paper, the histology and anatomy of soldiers heads of both species, using the scanning electronic microscope, is focused.

\section{MATERIAL AND METHODS}

Soldiers of Embiratermes festivellus (Nasutitermitinae) and Spinitermes brevicornutus (Termitinae) were collected in an area of cerrado vegetation at Corumbataí region, state of São Paulo, Brazil.

Histological Analysis: The termites were fixed in alcoholic Bouin's fluid, dehydrated in dioxane, embedded in paraffin and cut into $7 \mu \mathrm{m}$ sections. Slides were

1) Departamento de Biologia e Centro de Insetos Sociais, Universidade Estadual Paulista. Caixa Postal 199, 13506-900 Rio Claro, São Paulo, Brasil. 
stained with hematoxylin-eosin according to JUNQUEIRA \& JUNQUEIRA (1983) and examined with a Zeiss photomicroscope.

Scanning Electron Microscopy: Soldier heads were fixed in Karnovisky fixative and dehydrated in ethanol series (70 to 100\%) until acetone. They were then critical-point dried in CPD 030 Balzers and attached to adhesive surfaces on aluminum stubs. The material was coated with gold and observed in a JEOL JSM-P15 scanning electron microscope.
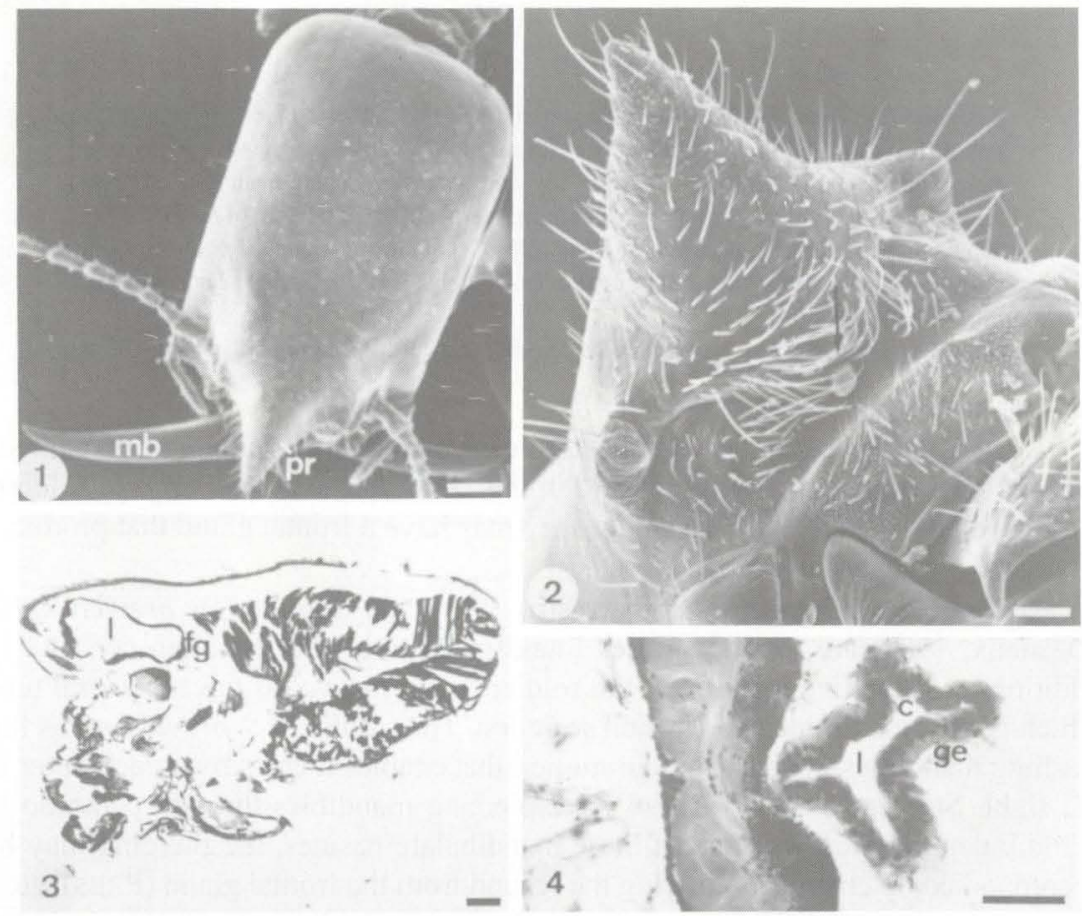

Figs 1-4. Soldier of Spinitermes brevicornutus. (1) Dorsal view of the head, scale: $100 \mu \mathrm{m}$; (2) detail of frontal projection, note the bristles and the opening of frontal gland sealed with glandular secretion (arrow), scale: $100 \mu \mathrm{m}$; (3) sagital section of the head, scale: $100 \mu \mathrm{m} ;(4)$ detail of the frontal gland, scale: $50 \mu \mathrm{m}$. Cuticle (c), lumem (I), glandular epithelium (ge), frontal projection (pr), mandible $(\mathrm{mb})$, frontal gland $(\mathrm{fg})$.

\section{RESULTS}

Field notes. The termite Embiratermes festivellus was collected directly from soil galleries or from galleries situated in an accumulation of dark soil in a ground surface. This aglomerated soil was more compact than adjacent soil, and was localized in clearings within study area. The termite Spinitermes brevicornutus was collected directly from soil galleries or from external galleries of Armitermes Wasmann, 1897 mounds. 


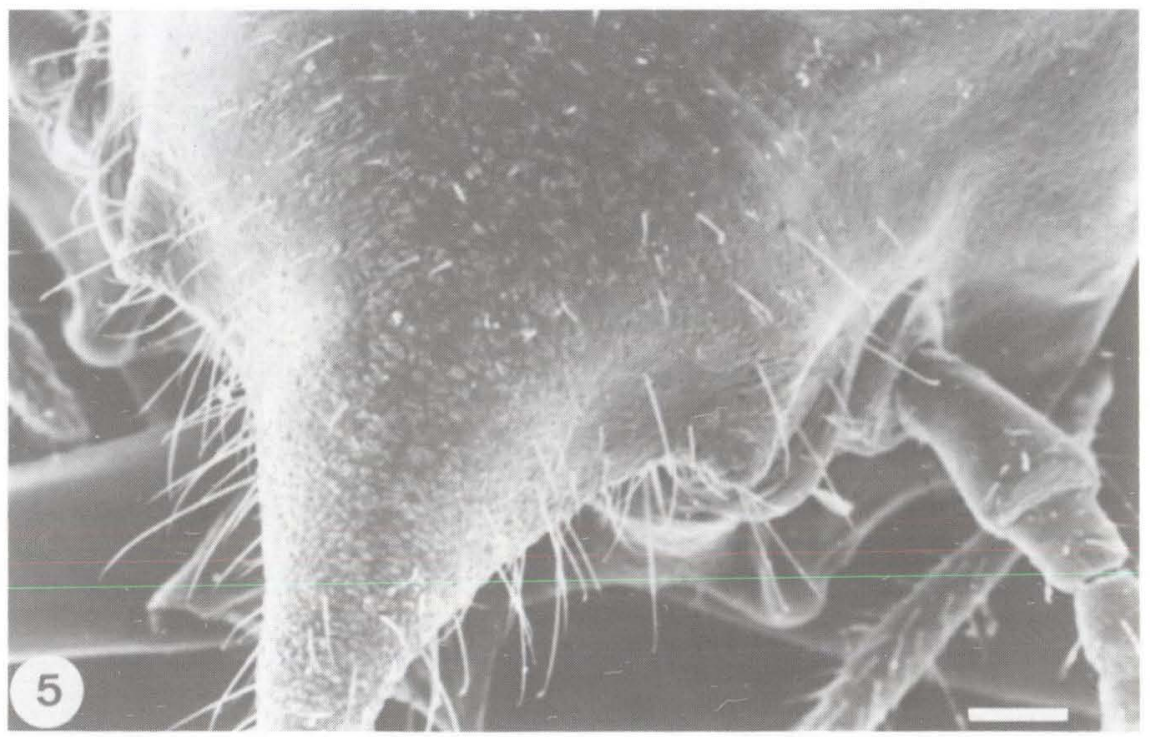

Fig. 5. Soldier of Spinitermes brevicornutus, scanning electron micrograph of the head, scale: $50 \mu \mathrm{m}$.

Morphological Data: The frontal projection is conical in S. brevicornutus soldier and seems different from the frontal tube (nasus) which is relatively long in E. festivellus soldier (Figs 1-2, 8, 12). The frontal gland forms a bag shape and is restricted to the head in both species (Figs 3, 9). Its opening (frontal pore) is located in the end of the frontal tube in E. festivellus (Fig. 8) and in the inferior basis of the conical projection (Fig. 2) in S. brevicornutus. The opening of the frontal gland is very small and obscure in this last species and generally it is sealed with glandular secretion as observed in the figure 2 (arrow).

The frontal gland of S. brevicornutus is small (Fig. 3), has a simple epithelium (Fig. 4) and is composed of class 1 glandular cells [classification of NOIROT \& QUENNEDEY $(1974,1990)]$. This epithelium is covered by a thick apical cuticle (Fig. 4).

The analysis of the frontal projection of this soldier with scanning electron microscope showed the presence of campaniform sensillae and characteristic saliences. (Figs 5-7). Among the salient structures are bristles with different lengths (Figs 2,6). A glandular opening in the saliences was not observed (Figs 6-7).

In E. festivellus the frontal gland penetrates more deeply to soldier head when compaired with that of S. brevicornutus (Fig. 9). The frontal gland also has a simple epithelium, class 1 cells with apical cuticle.

Free glandular cells are located in the upper part of the E. festivellus head (Fig. 10) and are organized in a pattern similar to the epithelium (Fig. 11). They probably belong to class 3 cells in NOIROT \& QUENNEDEY's classification. 

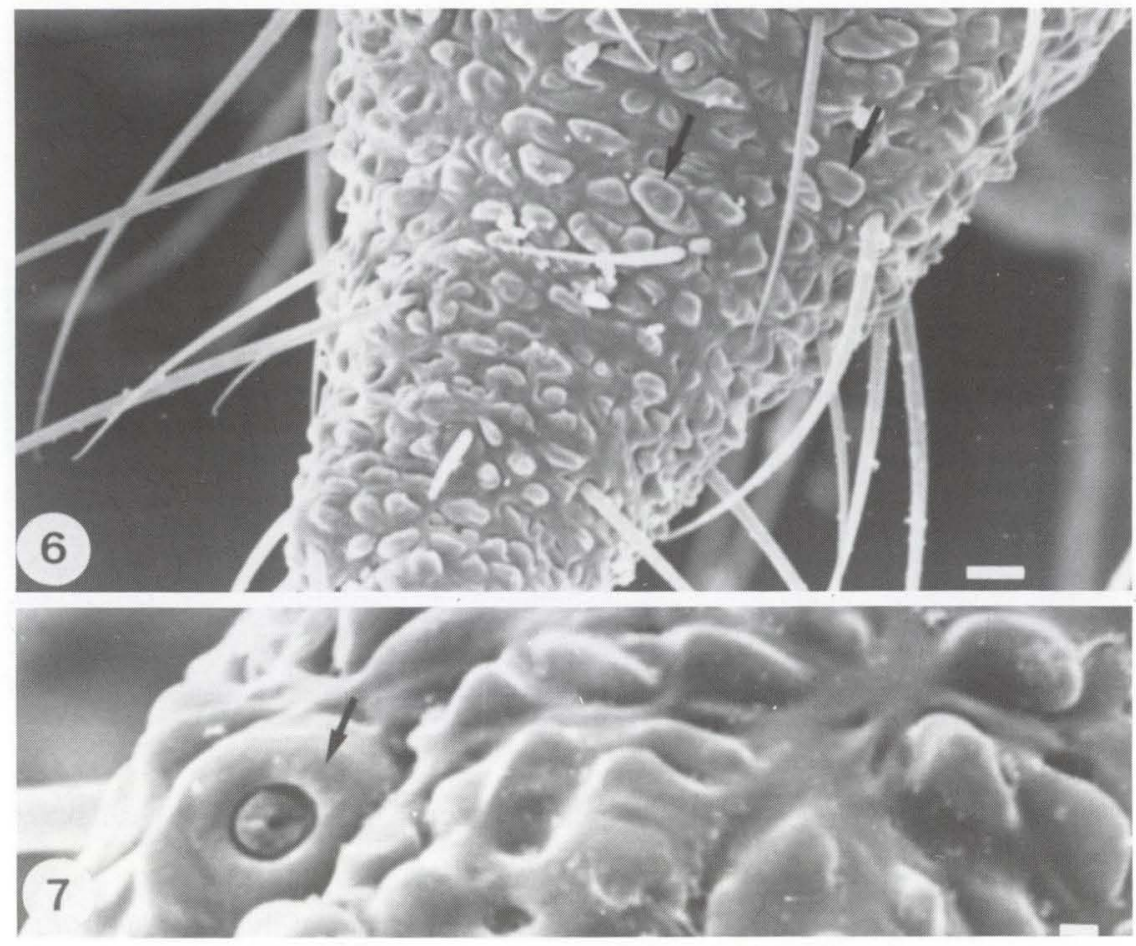

Figs 6-7. Soldier of Spinitermes brevicornutus. (6) Detail of the frontal projection with characteristic saliences (arrows) and bristles of different lengths, scale: $10 \mu \mathrm{m}$; (7) detailed view of campaniform sensillum (arrow) present in the frontal projection, scale: $1 \mu \mathrm{m}$.

A smooth frontal tube extremity and small protuberances in the frontal tube base (Fig. 12) and in the latero-superior head tegument (Fig. 13) of the E. festivellus soldier were visible with scanning microscopy. Among the protuberances (Figs 13-14) there are orifices (Fig. 15) that correspond to glandular openings besides campaniform sensillae (Fig. 16) and small bristles (Figs 13-14).

\section{DISCUSSION}

According to literature reports (ARAUJo 1970; MATHEWS 1977), the species E. festivellus is also found associated with mounds built by other species, including Embiratermes neotenicus (Holmgren, 1906), Cornitermes snyderi (Emerson, 1925 and Cornitermes bequaerti (Emerson, 1952). This association was never found in this study, possibly because we did not analyze many mounds in the cerrado area. However, S. brevicornutus presented this type of association, also reported by ARAujo (1970) and MATHEWS (1977) with Cornitermes Wasmann, 1897 mounds. Multioccupation of the mounds is a common defensive strategies of Neotropical subterranean termites. 

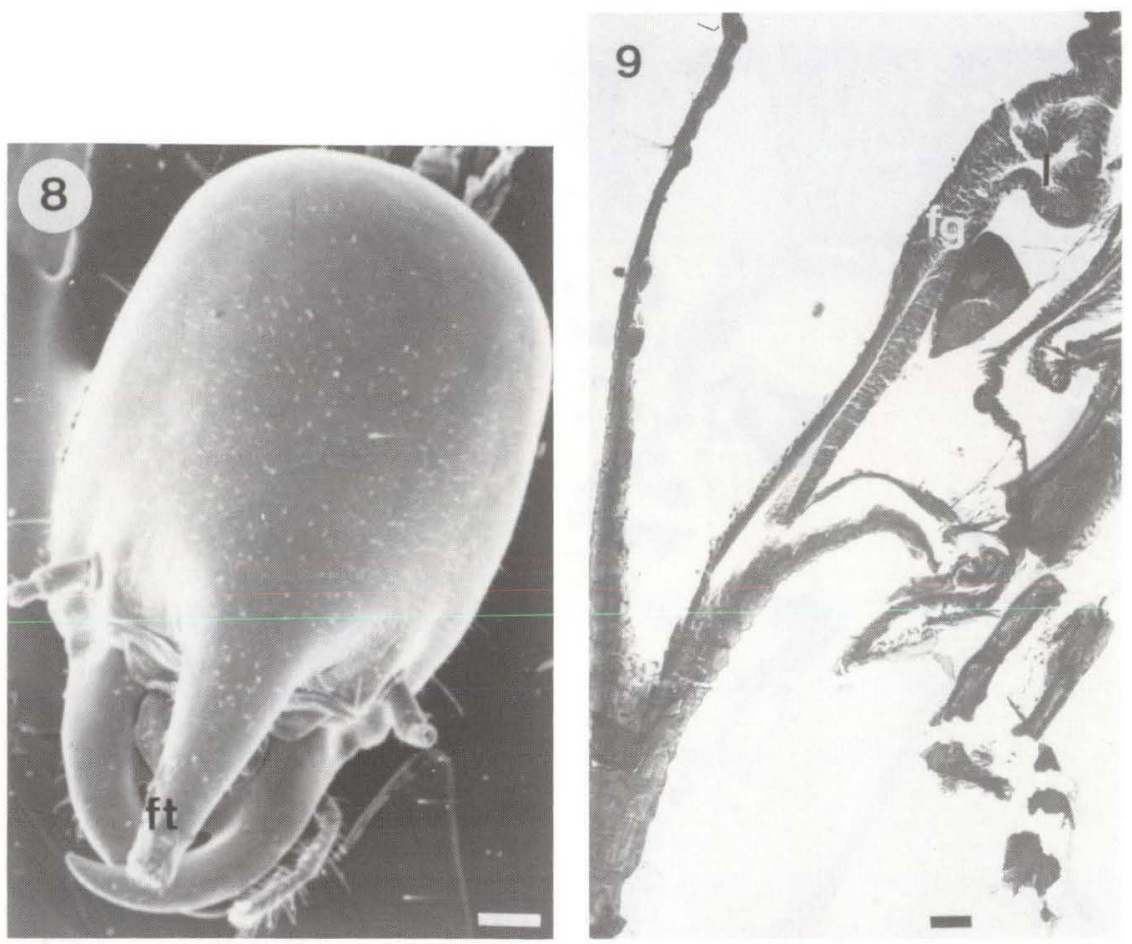

Figs 8-9. Soldier of Embiratermes festivellus. (8) Dorsal view of the head, scale: $100 \mu \mathrm{m}$; (9) parasagital section of the head showing the frontal gland, scale: $50 \mu \mathrm{m}$. Frontal tube (ft), frontal gland (fg), lumen (I).

The presence of the campaniform sensillae, as described in this paper (Figs $7,16)$, are frequent in the labrum of some termite soldiers of the family Rhinotermitidae (QUENNEDEY \& DELIGNE 1975) and in the frontal tube of some soldiers of the subfamily Nasutitermitinae (DELIGNE et al. 1981). The results with $S$. brevicornutus indicate these structures also seem to have a common occurrence in the head of some species within the subfamily Termitinae. Its position in the soldier heads confirms that these sensorial organs act in the perception of the distortion cuticle when the termite touches enemies or obstacles. The variable location of this sensillum in these soldiers may be relationed to defense mechanisms. Both termites have combined mechanical (mandibles) and chemical (frontal gland) defenses, but the function of the mandibles and the location of the frontal gland openings are different in E. festivellus and S. brevicornutus. The chemicals of the frontal gland are probably distinct as well. The dissimilar occurrence of the frontal pore in the two studied soldiers also concur to evidence the different evolution of the species defense which in termite is related with foraging and building behavior. Probably in $S$. brevicornutus the frontal secretion drains to the labrum and smears the mandibles. The presence of a very small and indistinct frontal gland opening among the Termitinae has already been discussed by MATEws (1977) and MiLLER (1991). 

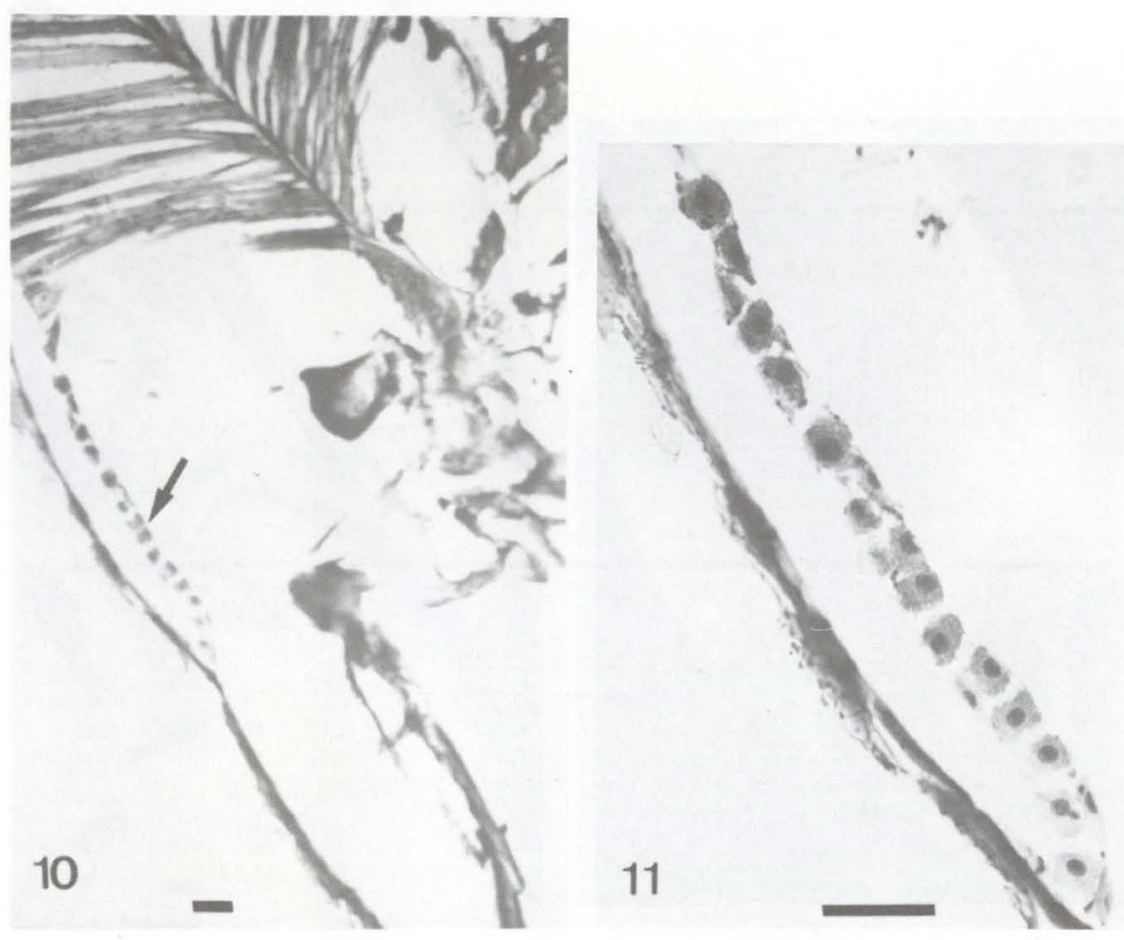

Figs 10-11. Soldier of Embiratermes festivellus. (10) Parasagital section of the head, arrow indicates the class 3 cells in the upper part of the head, scale: $50 \mu \mathrm{m}$; (11) detail of class 3 cells organized in a row, scale: $50 \mu \mathrm{m}$.

Evidence indicates that the quantity, diversity, and position of the bristles on the soldier head are also involved with sensorial function and defense mechanisms, but only a study of ultrastructure will confirm this fact.

The free glandular cells (Fig. 11) present in the upper part of the E. festivellus head are similar to those described in the rostral system of other Nasutitermitinae (QUENNEDEY 1984). The rostral system was first described by EMERSON (1960) in a nasute soldier, however he proposed a sensorial function to this system. Only later was the rostral system interpreted as a glandular system (DELIGNE 1973; DELIGNE et al. 1981). DELiGNE (1983) described this system in Verrucositermes hirtus Deligne, 1983 where it is composed of 2-7 glandular cells associated with special protuberances of the tegument denominated tubers. The protuberances observed in E. festivellus head are different from those tubers because they are smaller, round in shape, and do not have multiple glandular pores (Fig. 15). The frontal projection saliences observed in soldiers of S. brevicornutus are also different from the tubers of $V$. hirtus.

There are some hypotheses regarding the function of the rostral system. According to DeLigne et al. (1981), the product of these glandular cells prevents

Revta bras. Zool. 13 (2): 321 - 330, 1996 

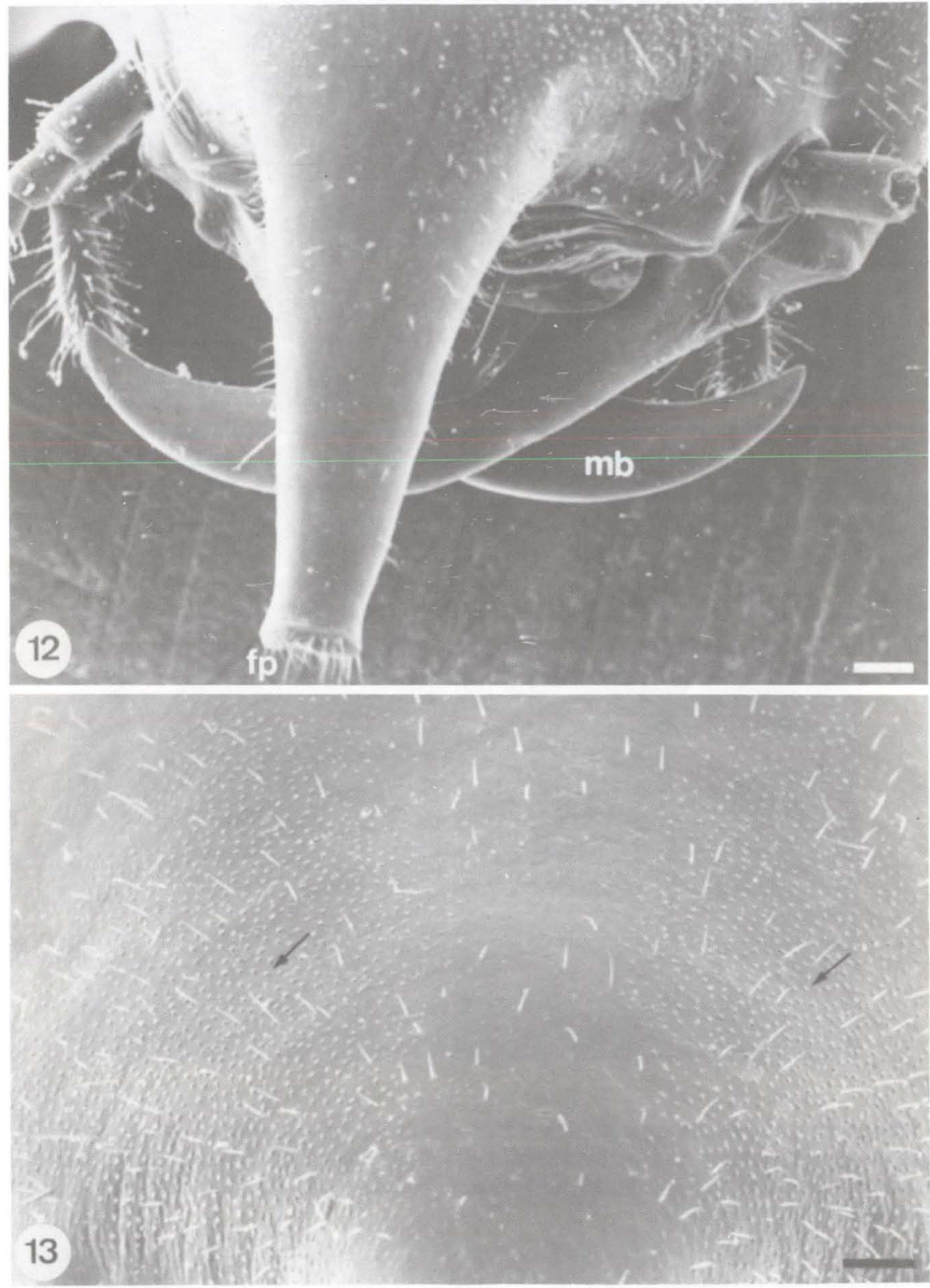

Figs 12-13. View of the upper and lateral surface of the head in an Embiratermes festivellus soldier. (12) Detail of smooth frontal tube extremity, note the bristles around the frontal pore, scale: $50 \mu \mathrm{m}$; (13) arrows indicate protuberances among the bristles on the lateral surface, scale: $50 \mu \mathrm{m}$. Frontal pore (fp), mandible $(\mathrm{mb})$. 

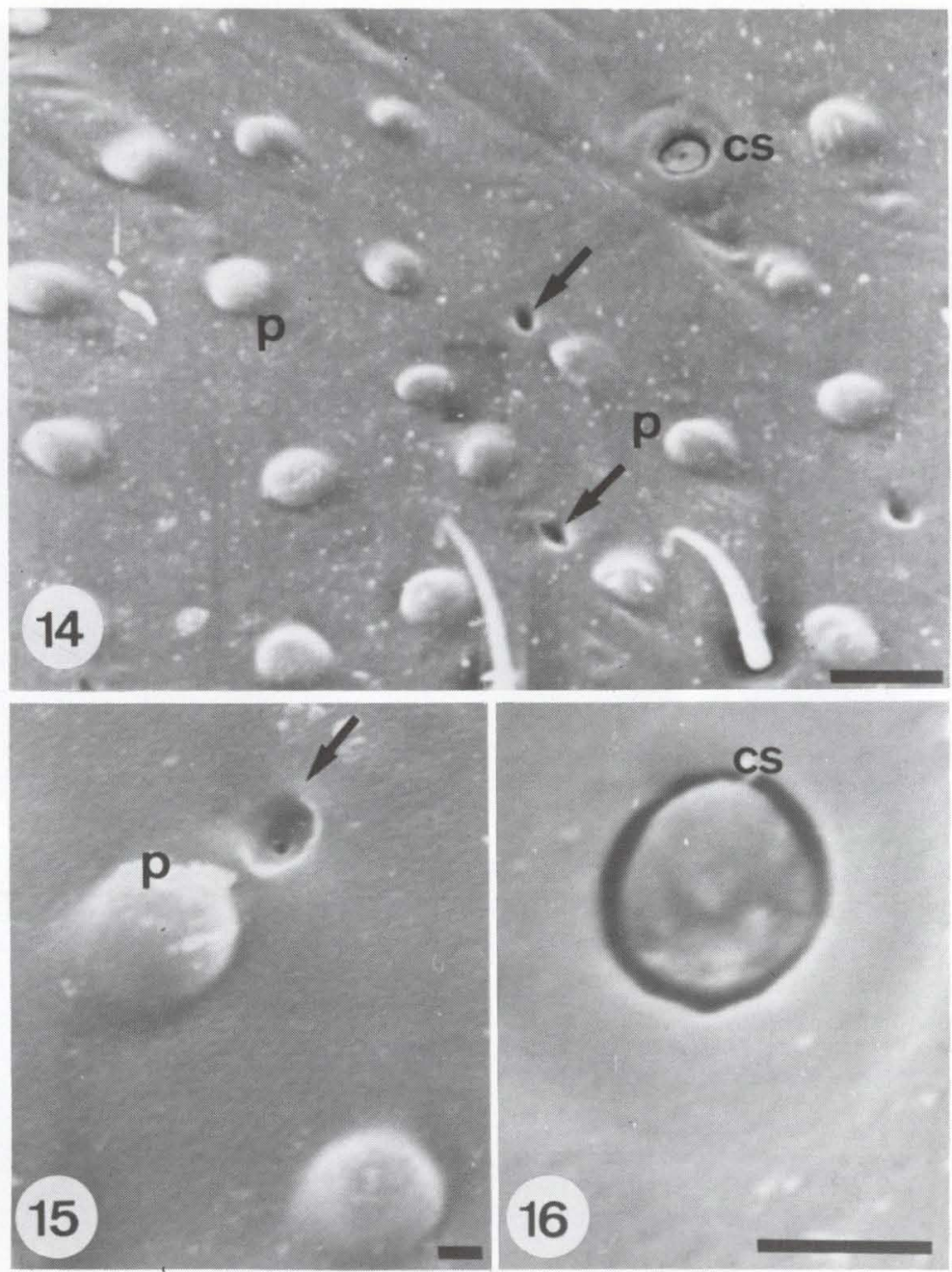

Figs 14-16. Latero-superior tegument of Embiratermes festivellus soldier. (14) General view showing the protuberances $(p)$; the arrows indicate glandular openings, scale: $5 \mu \mathrm{m}$; (15) detail of the protuberances and glandular opening (arrow), scale: $1 \mu \mathrm{m} ;(16)$ detail of the campaniform sensillum (cs), scale: $1 \mu \mathrm{m}$.

the heavy components of the frontal gland from sticking to its surface. PRESTWICH et al. (1982) considers that the glandular cells work as a contact detoxicant; he attributes a protector role to the rostral system. DELIGNE (1983) proposes a function in the alarm pheromone production. It was concur that the position of these glandular cells in E. festivellus suggests involvement with pheromone production, probably related to defense. 
In conclusion, the varied morphological organization of the frontal gland and isolated glandular cells (associated with modification of the soldier head tegument) may be correlated with the chemical diversity of defense secretions present in these different species of termite soldiers, mainly in relation to the defensive strategy developed by the subfamily Termitinae which is yet poorly known.

ACKNOWLEDGEMENTS. We thank Dr. Barbara L. Thorne for critical reading of the manuscript and Dr. L.R. Fontes by taxonomic identification. Financial support was provided by $\mathrm{CNPq}$.

\section{REFERENCES}

ARAUJO, R.L. 1970. Termites of the Neotropical region, p.527-571. In: K. KRISHNA \& F.M. WEESNER (Eds). Biology of termites. New York, Academic Press, vol. 2, XIV+643p.

DELIGNE, J. 1973. Observations au microscope életronique à balayage d'un nouveau système glandulaire céphalique chez les termites. Proc. Int. Congr. Int. Union Study Soc. Insects, 7th, 1973p.

- 1983. Description, développement et affinités de Verrucositermes hirtus sp.n. Fonction glandulaire des tubercules du soldat. Rev. Zool. Afr. 97 (3): 533-548.

Deligne, J.; A. QuenNedey \& M.S. Blum. 1981. The enemies and defense mechanisms of termites, p.1-76. In: H.R. HERMANN (Ed.). Social Insects. New York, Academic Press, 491p.

EMERSON, A.E. 1960. New genera the Subulitermes branch of the Nasutitermitinae from the Ethiopian region (Isoptera, Termitidae). Amer. Mus. Nov. 1987, p. $1-21$.

JUNQUEIRA, L.C.V. \& M.M.S. JUNQUEIRA. 1983. Técnicas básicas de citologia e histologia. São Paulo, Livraria Editora Santos, 123p.

MAtEws, A.G.A. 1977. Studies on termites from the Mato Grosso State, Brazil. Academia Brasileira de Ciências, 243p.

MiLler, L.R. 1991. A revision of the Termes-Capritermes Branch of the Termitinae in Australia (Isoptera: Termitidae). Invertebr. Taxon. 4: 1147-1282.

NoIROT, CH \& A. QUENNEDEY. 1974. Fine structure of insect epidermal glands. Ann. Rev. Entomol. 19: 61-81.

-1990. Glands, gland cells, glandular units: some comments on terminology and classification. Ann. Soc. Ent. Fr. 27: 123-128.

Prestwich, G.D. 1984. Defence mechanisms of termites. Ann. Rev. Entomol. 29: 201-232.

Prestwich, G.D.; S.G. SPANTAN; M. SchNeIdeR \& C. BleECHER. 1982. Biosynthesis and detoxications of termite-produced contact poisons, p.291. In: M.D. BREed; C.D. MichenER \& H.E. Evans (Eds). The biology of Social Insects. New York, Academic Press.

QUENNEDEY, A. 1984. Morphology and ultrastructure of termite defense glands, 
p.151-200. In: H.R. HERMANN (Ed.). Defensive mechanisms in social insects.

New York, Praeger Press.

Quennedey, A. \& J. Deligne. 1975. L'arme frontalle des soldats de termites. I.

Rhinotermitidae. Ins. Soc. 22 (3): 243-267.

Recebido em 31.VIII.1995; aceito em 19.VIII.1996. 